\title{
The Caddo and the Caddo Conference
}

Hiram F. Gregory

Unknown

Follow this and additional works at: https://scholarworks.sfasu.edu/ita

Part of the American Material Culture Commons, Archaeological Anthropology Commons, Environmental Studies Commons, Other American Studies Commons, Other Arts and Humanities Commons, Other History of Art, Architecture, and Archaeology Commons, and the United States History Commons

Tell us how this article helped you.

This Article is brought to you for free and open access by the Center for Regional Heritage Research at SFA ScholarWorks. It has been accepted for inclusion in Index of Texas Archaeology: Open Access Gray Literature from the Lone Star State by an authorized editor of SFA ScholarWorks. For more information, please contact cdsscholarworks@sfasu.edu. 


\section{The Caddo and the Caddo Conference}

Creative Commons License

(c) (i) (8)

This work is licensed under a Creative Commons Attribution-NonCommercial 4.0 International License 


\title{
The Caddo and the Caddo Conference*
}

\author{
Pete Gregory
}

There was one lone Caddo at the early Caddo Conference held at the University of Oklahoma campus-Mrs. Vynola Beaver Newkumet - then there was a long gap. In 1973, the Chairman of the Caddo Nation, Melford Williams, was the banquet speaker for the Conference, which was held in Natchitoches, Louisiana. A panel, consisting of Thompson Williams, Vynola Newkumet, Phil Newkumet, and Pete Gregory, was also part of that conference.

Subsequent to 1973, Caddo representatives have not only been invited, but have attended the majority of the conferences. Caddo Nation chairpeople who have attended include Melford Williams, Mary Pat Francis, Hank Shemayme, Hubert Halfmoon, Elmo Clark, Vernon Hunter, and La Rue Martin Parker. Over the years, tribal participation has grown. In 1985, the Caddo invited a panel to leave the conference in Norman, Oklahoma, to address the Caddo people at the tribal center at Binger, Oklahoma. Don Wyckoff, Frank Schambach, Dee Ann Story, Ann Early, Hester Davis, John Miller, Chuck Rohrbaugh, Wallace Chafe, and Pete Gregory talked to the tribal community about the language, history, and archaeology of the Caddo people. In the afternoon, the rest of the conferees came to Binger from Norman for a Turkey Dance, supper, and more dancing. This was the first dance for many of the anthropologists and archaeologists who were conference participants. Dee Ann Story was honored and given a shawl by the Caddo Nation.

That dialogue between the Caddo and the conferees has grown steadily, as have the contributions of tribal researchers and cultural representatives. The Caddo have done sessions at the conference on traditional music, dance, and clothing, on religion and material culture, and have participated in sessions on cultural landscapes, symbolism, and a variety of other topics. Phil and Vynola Newkumet introduced Caddo perspectives on history and culture early on, and Cecile Carter has added steadily to that voice, carrying it into the somewhat murky world of contract archaeology and the Euro-centric realm of historians. Caddo have sounded the voice of Caddo Nation more clearly since the passage of NAGPRA: David Scholes, Stacey Halfmoon, and Bobby Gonzalez have addressed Caddo culture, as well as the Federal regulations, well and repeatedly.

The Caddo Culture Club has literally taken Caddo music and dance "on the road," and held the first dance for the Caddo Conference at Moral, near Nacogdoches, Texas. The late Jim Corbin set the scene for a joint endeavor that has become a conference tradition. A Saturday night dance which always started with a Turkey Dance, then a meal, and then more traditional dancing, is a fond memory of everyone associated with the conference. Moreover, many of us have had the aid of the Caddo Culture Club in other joint endeavors. The Shuwititi young singers' and drummers group and the color guard have participated on several occasions. Conference attendees always leave with a sense of the Caddo Nation's deep-seated desire to preserve traditional culture and pass it on to their youth.

Over the years, Caddo people have used the conference as a site for honoring people who work with them on the preservation and maintenance of Caddo culture. Honors have included traditional gifts-a Pendleton blanket, a shawl, ceramic vessels - and in the past few years, handsome plaques. The traditions of archaeology and the Caddo have melded well together and this separates the Caddo Conference from other such events across the country. 
This sense of cooperation has been with the Caddo Conference for a long time, and each year the Caddo participation has increased. The Caddo expertise has introduced the living culture even while listening to non-Caddo people talk about the past. Some will recall the visit to the Hinton dance ground, to the home of Mr. Whitebead, others the hospitality of Lefty and Doris Williams. Many lessons taught, much left to learn. Together both conferees and the Caddo have begun to see the link that hold us all together-a deep interest in Caddo Culture. In 2007, the Caddo conferees went to Battle Mound and the Crenshaw site. Some have attended reinterment ceremonies, visited sacred sites, and come away with a deep respect for the strength of Caddo culture and religious tradition. While other academic conferences are only now beginning to learn what the Caddo taught this conference early on-we need to remember that the contributions of Caddo people continue to teach us how to better understand what we mutually share.

* Pete Gregory teaches at Northwestern Louisiana University. This article is reprinted with permission from: " $50^{\text {th }}$ Caddo Conference: A Retrospective, Natchitoches, Louisiana, 2008." 